\title{
BRAINSTEM AUDITORY EVOKED RESPONSE IN NORMAL TERM NEONATES
}

\author{
Laura M. F. F. Guilhoto ${ }^{1}$, Virgínia S. Quintal2 ${ }^{2}$ Maria T. Z. da Costa ${ }^{2}$
}

\begin{abstract}
Brainstem auditory evoked response (BAER) is a reliabletest for neonatal auditory and neurological dysfunction and it permits early diagnosis and rehabilitation. The purpose of this study is to demonstrate latencies of BAER in normal term neonates in order to obtain reference values in a university hospital. BAER was performed in the second day of life in 47 normal newborns ( 25 male, 22 female) which gestational ages were higher than 37 and lower than or equal to 40 weeks that did not present familial history of deafness. The exam was performed with $80 \mathrm{dBHL}$ alternating polarity 10/sec clicks presented monaurally. Two thousand stimulus trials were averaged and duplicated for each ear. Mean wave latencies in msec was: I, 1.79 (SD 0.20); II, 2.88 (SD 0.28); III, 4.54 (SD 0.31); IV, 5.86 (SD 0.36); V, 6.75 (SD 0.38); inter-peak latencies (IPL) I-III, 2.75 (SD 0.36); IPL III-V, 2.22 (SD 0.22); and IPL I-V, 4.97 (SD 0.43).
\end{abstract}

KEY WORDS: newborn, evoked responses, brainstem, normative values.

\section{Potencial evocado auditivo de tronco cerebral em recém-nascidos normais a termo}

RESUMO - O estudo do potencial evocado auditivo de tronco cerebral (PEA-TC) é um teste diagnóstico útil de disfunção auditiva e neurológica neonatal permitindo reabilitação precoce. O objetivo deste estudo é obter dados normativos das latências do PEA-TC em recém-nascidos normais a termo em hospital universitário. PEA-TC foi registrado no segundo dia de vida em 47 recém-nascidos normais ( 22 femininos e 25 masculinos) com idades gestacionais superiores a 37 e inferiores ou iguais a 40 semanas, que não apresentassem antecedentes familiares de déficit auditivo. 0 tempo de latência de 2.000 estímulos promediados e uma replicação foram estudados para cada ouvido, utilizando-se clicks monoaurais alternantes de $80 \mathrm{dBHL}$ a 10/s. A média em milisegundos da latência das ondas foi: I, 1,79 (DP 0,20); II, 2,88 (DP 0,28); III, 4,54 (DP 0,31); IV, 5,86 (DP 0,36); V, 6,75 (DP 0,38); latências interpico (UP) I-III, 2,75 (DP 0,36); LIP III-V, 2,22 (DP 0,22); e LP I$\mathrm{V}, 4,97(\mathrm{SD} 0,43)$.

PALAVRAS-CHAVE: recém-nascido, potencial evocado, tronco encefálico, normatização

Brainstem auditory evoked response(BAER) reflects non-propagated, volume-conducted events, which manifest the sequential activation of auditory brainstem nuclei and pathways ${ }^{1,2}$. A series of 5-7 waves can be recorded and are related to the following regions of auditory pathway: wave I, segment of the eighth nerve close to the cochlea; wave II, intracranial portion of the eighth nerve close to the brainstem and cochlear nucleus in pons; wave III, superior olivary complex (pons); wave IV, mid and upper pons; wave $\mathrm{V}$, lateral lemniscus (upper pons) or inferior colliculus (low midbrain)3. It has been observed a progressive decline in the latency of wave $V$ and interpeak latency I-V from neonatal period to around infancy ${ }^{4-6}$ and childhood until achieving adult values. These evoked responses though, may indicate some physiological dysfunction in the auditory system up to the brainstem level. Since clinical semiology is poor in neonates, this type of non-invasivetests may objectively evaluate the integrity of this pathway, as well the surrounding areas in the brainstem. It turns out to be a reliable test for auditory and neurological dysfunction at this age and it permits early diagnosis and rehabilitation.

There are few reports of normative values of BAER in neonatal period, especially in development nations ${ }^{7-8}$. There is a need to have reference guides for laboratories in every country to establish a standard routine of investigation.

The purpose of this study is to demonstrate the latencies of BAER in normal term neonates in order Setor de Neurofisiologia Clínica da Divisão de Clínica Médicaª e Unidade Neonatal da Divisão de Clínica Pediátrica² do Hospital Universi-
tário da Universidade de São Paulo (HU-USP), São Paulo SP, Brasil.

Received 31 March 2003, received in final form 11 July 2003. Accepted 5 August 2003.

Dra. Laura M. F. Ferreira Guilhoto - Setor de Neurofisiologia Clínica da Divisão de Clínica Médica do HU-USP - Avenida Lineu Prestes 2565 - 05508-900 São Paulo SP - Brazil. E-mail: lauragui@usp.br 
to obtain normative data in a university hospital of São Paulo, Brazil, a city with 20 million habitants.

\section{METHOD}

BAER was performed between 48 and 96 hours of life in 47 normal newborns in the University Hospital of the University of São Paulo. Normal newborns ( 25 male, 22 female) were evaluated, with adequate weight for gestational age (GA), which were higher than 37 and lower than or equal to 40 weeks (Dubowitz). The patients presented no familial history (parents and siblings) of deafness and had fifth minute Apgar scores higher than 7 and negative elluate and Coombs reactions. The patients did not presented any neonatal distress with exception of mild physiological jaundice without need of phototherapy.

The exam was performed during sleep, after feedings in the morning, using $80 \mathrm{dBHL}$ clicks of alternating polarity presented monaurally at a rate of $10 / \mathrm{sec}$. A total of 2000 stimulus trials was averaged and duplicated for each ear (analysis time $10 \mathrm{msec}$, filters $100-3.000 \mathrm{~Hz}$ ).

\section{RESULTS}

The mean latency time of waves I, II, III, IV, V and the inter-peak latencies (IPL) were measured. The mean of the latencies in milliseconds was the following: wave I, 1.79 (SD 0.20); wave II, 2.88 (SD 0.28); wave III, 4.54 (SD 0.31); wave IV, 5.86 (SD 0.36); wave V, 6.75 (SD 0.38); IPL, I-III, 2.75 (SD 0.36); III-V, 2.22 (SD 0.22); and finally I-V, 4.97 (SD 0.43).

When we compare the results of the present study with the values obtained in healthy adults with similar methodology in our laboratory, we observed a clear decrease in latency values in these latter. The greatest discrepancy was wave $V$ latency, as well as inter-peak latencies, showed in Figures 1 and 2, respectively.

\section{DISCUSSION}

Our results were similar to other authors that studied BAERs in neonates'.

Several studies ${ }^{9-12}$ observed that hearing thresholds (wave $V$ ) of newborn infants diminish with increasing age. Instead, wave I does not seem to have the same velocity of decrease trough adult levels especially when different stimulus rates are used ${ }^{13}$. This fact probably reflects that maturation of auditory pathways may involve different mechanisms in central and peripheral areas ${ }^{14}$. Starr et al. ${ }^{15}$ have suggested that peripheral changes manifested by decrease of wave I latency could include impedance changes in the middle ear, the maturation of highfrequency sensitivity of the cochlea or changes in transduction between hair cells and the dendrites of VIII nerve.

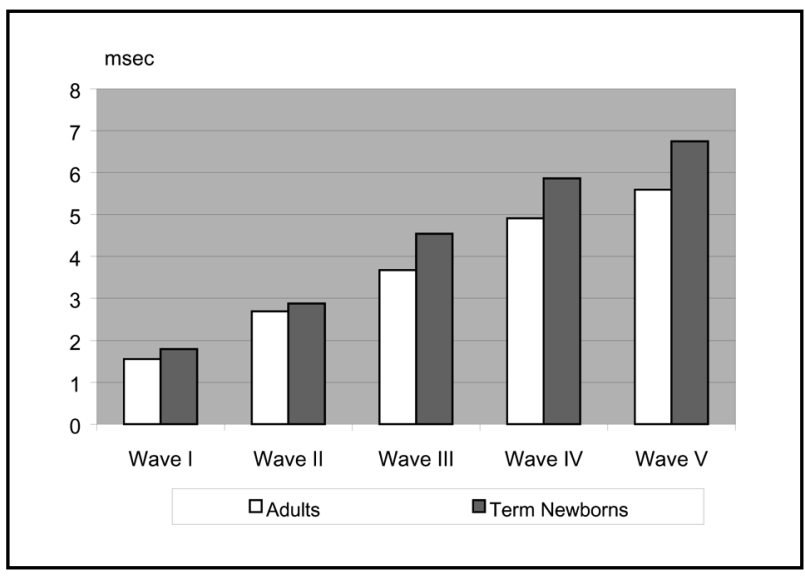

Fig 1. Normal newborn and adult BAER mean latency values in our laboratory.

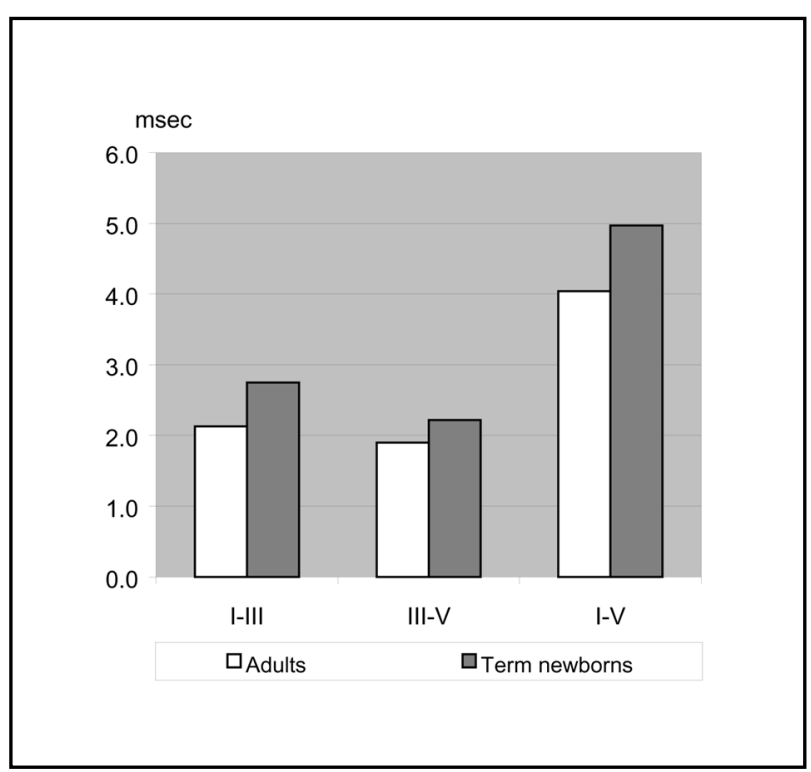

Fig 2. Normal newborn and adult BAER mean IPL values in our laboratory.

Central conduction could involvechanges in nerve conduction velocity associated with myelination and/ or changes in synaptic efficiency at the various nuclei of the auditory pathway ${ }^{16}$. Maturation of human central auditory system extends into adolescence, and certain auditory processing skills such speech recognition have a prolonged time course ${ }^{17}$.

BAER in neonates may be abnormal in congenital deafness, anoxia, central nervous system infection, toxic states such as during antibiotics treatment, jaundice, intrinsic brain stem lesion, such as tumors, vascular pathologies (infarctions, hemorrhages, malformations) and coma3,18.

Beverly et al. ${ }^{19}$ found that BAER were not a good prognostic indicator of future neurodevelopmental disability or outcome in neonatal period. Salamy and 
Eldredge $\mathrm{e}^{20}$ have demonstrated a higher risk of BAER abnormalities in the nursery in normal hearing infants that had neurological signs or brain anomalies and those exposed to cocaine in utero.

\section{CONCLUSION}

Normative BAER studies in term neonates performed in university hospitals are necessary to establish reference values for evaluation of auditory and neurologic prognostic factors as well as to early diagnose children with risk of auditory dysfunction.

Acknowledgments - The authors wish to acknowledge the helpful suggestions of Dr. Francisco J. C. Luccas, director of the Neurophysiology Section of Albert Einstein Hospital, São Paulo, Brazil, as well the cooperation of technicians Eliane A. Abreu and Eliane Ornelas with the study.

\section{REFERENCES}

1. Jewett DL, Romano MN, Williston JS. Human auditory evoked potentials: possible brain stem components detected on the scalp. Science 1970;167:1517-1518.

2. Picton TW, Hillyard SA, Krausz HI, Galambos R. Human auditory evoked potentials: I. Evaluation of components. Eletroencephalograph Clin Neurophysiol 1974;36:179-190.

3. Chiappa KH. Brain stem auditory evoked potentials: interpretation. In Chiappa KH (ed). Evoked potentials in clinical medicine. New York: Raven Press, 1995:223-305.

4. Golstein PJ, Krumholz A, Felix JK, Shannon D, Carr RF. Brain stemevoked response in neonates. A m J Obst Gynecol 1979;135:622-639.

5. Hecox K, Galambos R. Brain stem auditory evoked responses in human infants and adults. Arch Otolaryngol 1974;99:30-33.
6. Salamy A, McKean CM, Buda FB. Maturation of contralateral brainstem responses in preterm infants. Brain Res 1975;96:361-366.

7. Deorari AK, Garg R, Bisht MS, A huja GK, Paul VK, Singh M. A uditory brain stem evoked response in normal neonates and infants. Indian Pediatr 1989;26:981-986.

8. Jiang ZD, Zhang L, Wu YY, Liu XY. Brainstem auditory evoked responses from birth to adulthood: development of wave amplitude. Hear Res 1993;68:35-41.

9. Gorga MP, Reiland JK, Beauchaine KA, Worthington DW, Jesteadt W. Auditory brainstem responses from graduates of an intensivecare nursery: normal patterns of response. J Speech Hear Res 1987;30:311-318.

10. Despland PA, Galambos R. Use of the auditory brainstem responses by prematures and newborns infants. N europädiatrie 1979;11:99-107.

11. Lary S, Briassoulis G, Vries L, Dubowitz L, Dubowitz V. Hearing threshold in preterm and term infants by auditory brainstem response. J Pediatr 1985;107:593-599.

12. Morgon A, Salle B. A study of brain stem evoked responses in prematures. Acta Otolaryngol 1980;89:370-375.

13. Lina-Granade G, Collet L, Morgon A, Salle B. Maturation and effect of stimulus rate on brainstem auditory evoked potentials. Brain Develop 1993;4:263-269.

14. Salamy A, McKean CM. Postnatal development of human brainstem potentials during the first year of life. Electroenceph, Clin N europhysiol 1976; $40: 418-426$.

15. Starr A, A mille RN, Martin WH, Sanders S. Development of auditory function in newborn infants revealed by auditory brainstem potentials. Pediatrics 1977;60:831-839.

16. Ken-Dror A, Pratt H, Zeltzer M, Sujov P, Katzir J, Benderley A. A uditory brain-stem evoked potentials to clicks at different presentation rates: estimating maturation of pre-term and full-term neonates. Electroenceph Clin Neurophysiol 1987;68:209-218.

17. Ponton CW, Eggermont JJ, Kwong B, Don M. Maturarion of human central auditory system activity: evidence from multi-channel evoked potentials. Clin Neurophysiol 1999;111:220-236.

18. Hecox KE, Cone BC. Prognostic importance of brainstem auditory evoked responses after asphyxia. Neurology 1981;31:1429-1433.

19. Beverley DW, Smith IS, Beesley P, Jones J, Rhodes N. Relationship of cranial ultrasonography, visual and auditory evoked responses with neurodevelopmental outcome. Dev Med Child Neurol 1990;32:210-222.

20. Salamy A, Eldredge L. Risk for ABR abnormalities in the nursery. Electroenceph Clin Neurophysiol 1994;92:392-395. 